\title{
Effects of the moisturizing cream containing yellowish natural colorants on the skin improvement
}

\author{
Hwa-Jin Suh ${ }^{1}$ Yeon-Soon Kim ${ }^{1} \cdot$ Sanggyu Park $^{1} \cdot$ Shin Park $^{1}$

\section{황색계 천연색소 추출물이 함유된 보습크림의 피부개선 효과}

서화진 ${ }^{1} \cdot$ 김연순 $^{1} \cdot$ 박상규 $^{1} \cdot$ 박 $\quad$ 신 $^{1}$

Received: 20 April 2017 / Accepted: 29 May 2017 / Published Online: 30 June 2017

(C) The Korean Society for Applied Biological Chemistry 2017

\begin{abstract}
This study was to evaluate the effect of the moisturizing cream containing five kinds of plants extracts for human facial improvements such as hydrating ability, transepidermal water loss and erythema reaction. The antioxidant activities of yellowish natural colorants, extracted from five kinds of plants (Ceramium kondoi, Phellodendron amurense, Carthamus tinctorius, Gardenia jasminoides for. grandiflora and Aphis chinensis) were tested. Twenty-one volunteers were subjected to analyze the effects, and each result was determined by treating the complex cream containing plants extracts on their skin in three times. The moisture content on skin was significantly increased more than $50 \%$ by treating the cream containing five kinds of plants extracts. The transepidermal water loss was reduced and the level of the skin erythema reaction was improved after treatment of the complex cream. Survey analysis showed that the volunteers had highly satisfaction on the tested creams. The results suggest that the complex cream containing five plants extracts had an improved effect on facial skin, and therefore can be used as moisturizing ingredients in the related industry.
\end{abstract}

Keywords Antioxidant · Erythema reaction · Moisturizing cream · Transepidermal water loss

Shin Park $(\bowtie)$

E-mail: spark@daegu.ac.kr

${ }^{1}$ Division of Life and Environment, Daegu University, Gyeongsan 38453, Republic of Korea

This is an Open Access article distributed under the terms of the Creative Commons Attribution Non-Commercial License (http://creativecommons. org/licenses/by-nc/3.0/) which permits unrestricted non-commercial use, distribution, and reproduction in any medium, provided the original work is properly cited.

\section{서 론}

경제 수준이 향상되고 평균수명의 연장으로 인하여 건강한 삶 과 더불어 아름다운 피부를 유지하기 위해 많은 노력과 관심을 기울이고 있다. 20대 이후부터 진행되는 피부노화는 모공 확장 에 따른 탄력 감소로 피부 처짐에 의한다(Choi과 Ahn 2010). 이러한 피부노화를 억제하기 위한 연구로 최근 madecassic acid 에 대한 관심과 응용성에 대한 연구가 많이 진행되고 있어 이 를 함유하고 있는 식물 또는 이와 유사한 기능의 식물 추출물 에 대한 연구가 진행되고 있다(Won 등, 2010). 식물체내 존재 하는 플라보노이드 성분들은 건강증진과 질병에 대한 예방뿐만 아니라 피부건강에 다양한 역할을 하고 있으며, 대부분의 플라 보노이드 성분들은 생체 내에서 항산화활성, 혈소판응집 억제, 항염증활성, 항암작용 및 피부노화 방지 등을 도와주는 것으로 알려져 있다(Craig 1997).

현재 우리 주변에서 접할 수 있는 천연유래 항산화 및 항노 화 기능성 소재로는 비타민E, 비타민C, 탄닌, 안토시아닌, 카로 티노이드류, 플라보노이드류 등이 있으며 생체 내에서 노화를 억제시키거나, 피부개선, 동맥경화, 염증, 퇴행성질환, 암을 예방 하는데 아주 효과적인 것으로 보고되어 있다(Ali 등, 2005; Elzaawely 등, 2005). 이러한 천연 항산화제는 대부분 색을 띄 고 있으며 전통적으로 사용되어져 온 천연염색의 소재인 천연 염료의 주성분과 일치한다. 최근에 안토시아닌류, 탄닌류, 커큐 민류, 라이코펜 등 26 종의 천연색소가 미국에서 사용허가를 받 았다고 알려져 있으며, $\mathrm{EU}$ 에서는 40여종의 색소가 첨가제로 등 록이 되어 있다(Dabas 등, 2011). 이러한 천연색소는 온도, 빛, 산화제, 환원제, 산도 및 보관성 등과 같은 요인에 의해 영향을 받을 수 있어 아직까지는 합성색소에 비해 산업적 적용성이 낮 다고 할 수 있다. 일반적으로 천연에서 유래된 색소는 섬유 및 종이 염색에 사용하는 것으로 알고 있었으나 이들 색소성분의 다양한 기능성 및 안전성에 대한 연구를 통해 새로운 천연 항 
산화제로서의 가치 연구가 필요하다. 한편, 대극속(Euphorbia L.)에 속하는 비단풀(Ceramium kondoi)은 여러해살이풀로 전국 적으로 야생하며 백색의 유액을 함유하며, 주요성분은 flavonoid (quercetin), gallic acid, tannin 등을 함유하여 강력한 항산화 효 과를 바탕으로 항암, 해독작용, 항균, 진정작용이 뛰어나서 여 러 종류의 암, 염증, 천식, 당뇨병, 심장병, 신장질환 및 정신불 안증 등에 효과적인 것으로 알려져 있다 (An 등, 2006; Kwon 등, 2016).

본 연구는 상처치유, 혈액순환 촉진, 잔주름방지, 가려움증 진 정작용에 효과적이라고 알려지 있는 비단풀과 황색계 천연색소 (황백, 홍화, 치자, 오배자) 추출물을 이용한 기능성 화장품을 제 조하기 위하여 이들을 첨가한 보습크림제품에 대해 보습, 홍반 반응을 분석하였으며 피부자극 완화 효과를 연구하였다.

\section{재료 및 방법}

\section{실험재료 및 연구 대상}

비단풀(Ceramium kondoi), 황백(Phellodendron amurense), 홍화 (Carthamus tinctorius), 치자(Gardenia jasminoides for grandiflora) 및 오배자(Aphis chinensis)는 경북 영천시에서 구입하여 분쇄기 를 사용하여 분쇄한 분말을 냉동 보관하면서 실험에 사용하였 다. 시료의 학명, 일반명 및 사용된 부위에 대해서는 Table 1에 나타내었다. 각 분쇄 시료 $100 \mathrm{~g}$ 에 $50 \%$ 에탄올 $1 \mathrm{~L}$ 를 첨가하 여 $70{ }^{\circ} \mathrm{C}, 5$ 시간 추출하였으며, 추출액은 Whatman No. 1 여과 지로 여과한 후 감압농축기 및 동결건조기를 이용하여 분말 시 료를 제조하여 실험용 크림 제형 제조에 사용하였다. 실험에 사 용된 용매 및 시약은 Duksan (GR grade), Sigma-Aldrich Co. (St. Louis, MO, USA) 제품을 사용하였다.

본 연구에 사용된 피부개선효과 평가용 시료는 경북 영천지 역의 $\mathrm{K}$ 사에서 제공받은 기본 보습크림에 식물복합추출물을 첨 가한 보습크림 제형을 제조하여 사용하였다. 즉 비단풀, 황백, 홍화, 치자 및 오배자 등 식물복합추출물을 각각 $1 \%(\mathrm{w} / \mathrm{v})$ 용 액으로 만든 후 기존 보습크림에 $1 \%$ 중량비로 함유시켜 제조 하였다.

식물복합추출물을 함유한 보습크림의 피부개선 효과를 판단 하기 위해 20-50대 여성 21명을 선정하여 임상연구를 수행하였 다. 본 연구에 참여한 피험자의 기본 정보는 20 대 1 명, 30 대 12 명, 40대 7명, 50대 1명으로 총 21명의 여성으로 구성되었 다. 피부상태 특성으로 피부타입은 건성 7명, 중성 8명, 복합성 6명 이었으며, 피부색은 대체로 하얀편 또는 보통이었으며 피부 표면상태, 피부유분 및 피부수분은 전체적으로 조화롭게 구성되

Table 1 Plants and their parts that were used in this study

\begin{tabular}{lccc}
\hline \multicolumn{2}{c}{ Sample } & \\
\cline { 1 - 2 } Scientific name & \multicolumn{2}{c}{ Common name } & \\
\cline { 1 - 2 } Ceramium kondoi & Ceramiaceae & 비단풀 & Whole \\
Phellodendron amurense & Amur cork & 황백 & Bark \\
Carthamus tinctorius & Safflower & 홍화 & Flower \\
Gardenia jasminoides for. grandiflora & Gardenia & 치자 & Fruit \\
Aphis chinensis & Gall nut & 오배자 & Whole \\
\hline
\end{tabular}

었다. 시료의 처리는 하루 2 회 크림을 각 시험부위에 적당량 도 포하였으며, 측정 및 평가는 지정된 세안제로 시험부위를 세정 한 후 공기의 이동과 직사광선이 없으며 항온항습 조건이 유지 되는 공간에서 20 분간 피부를 안정시킨 후 육안, 기기측정(피부 수분량, 경피수분손실량, 피부색(홍반-a* value)) 및 설문평가를 실시하였다.

\section{총 페놀 함량 분석}

추출된 시료의 총 폴리페놀 함량을 평가하기 위해 각각의 5종 시료 $10 \mathrm{mg}$ 을 혼합하여 $5 \mathrm{~mL}$ 의 증류수에 녹인 후 FolinCiocalteu법(Sato 등, 1996)으로 분석하였다. 즉 시료 $100 \mu \mathrm{L}$ 와 Folin-Ciocalteu 시약 $50 \mu \mathrm{L}, 20 \% \quad \mathrm{Na}_{2} \mathrm{CO}_{3} 850 \mu \mathrm{L}$ 를 혼합한 후 2시간 동안 암실에서 보관한 후, 분광광도계(UV-1800 Shimadzu, Kyoto, Japan)를 이용하여 $765 \mathrm{~nm}$ 에서 측정하였다. 총 페놀 함량은 gallic acid를 이용하여 표준 검량선을 작성하 여 총 폴리페놀 함량을 시료 $1 \mathrm{mg}$ 중의 $\mathrm{mg}$ gallic acid로 계산 하였다. Gallic acid의 농도는 $10-500 \mathrm{mg} / \mathrm{mL}$ 가 되도록 하여 위 와 같은 방법으로 $765 \mathrm{~nm}$ 에서 흡광도를 평가하여 작성하였다.

\section{DPPH radical 소거활성 측정}

Brand-Williams 등의 방법(Szabo 등, 2007)에 따라 2,2-diphenyl1-picrylhydrazyl (DPPH) 라디칼 소거 활성을 평가하였다. 식물 복합추출물(비단풀, 황백, 홍화, 치자, 오배자)은 5 종의 추출물을 동량 $(2 \mathrm{mg})$ 으로 혼합하여 $10 \mathrm{mg} / \mathrm{mL}$ 농도의 stock solution으로 사용하였다. 즉 $6 \times 10^{-5} \mathrm{M} \mathrm{DPPH}$ 를 methanol에 녹인 후, $\mathrm{DPPH}$ 라디칼 용액 $900 \mu \mathrm{L}$ 와 시료 $100 \mu \mathrm{L}$ 를 혼합한 후 5 분간 반응시 킨 후 분광광도계(UV-1800 Shimadzu, Japan)를 사용하여 517 $\mathrm{nm}$ 에서 흡광도를 평가하였다. DPPH 라디칼의 소거능은 아무 것도 첨가하지 않은 대조군과 시료 첨가 후 흡광도의 변화로 하여 다음 식으로 계산하였다.

$$
\begin{gathered}
\mathrm{DPPH}, \mathrm{ABTS} \text { radical decolorization (\%) } \\
=\left(1-\frac{\text { 시료첨가구의 흡광도 }}{\text { 무처리구의 흡광도 }}\right) \times 100
\end{gathered}
$$

\section{ABTS radical 소거활성 측정}

2,2'-azino-bis(3-ethylbenzothiazoline-6-sulfonic acid) diammonium salt (ABTS) 라디칼 소거활성을 이용한 항산화력 측정은 $\mathrm{ABTS}$ cation decolorization assay 방법(Roberta 등, 1999)에 의하여 측정하였는데, $7 \mathrm{mM}$ ABTS와 $2.4 \mathrm{mM}$ potassium persulfate를 섞어 12 시간 이상 암소에 방치하여 청록색의 $\mathrm{ABTS}$ 라디칼을 형성시켜 냉장 보관하였으며, radical stock solution은 $734 \mathrm{~nm}$ 에 서 흡광도 값이 $0.70( \pm 0.02)$ 이 되도록 에탄올로 희석하였다. 이 용액 $0.9 \mathrm{~mL}$ 에 농도별로 제조한 각 시료용액 $0.1 \mathrm{~mL}$ 를 가한 후 실온에서 7분간 반응시킨 후, 반응액의 흡광도 변화를 $734 \mathrm{~nm}$ 에서 측정하였다. ABTS radical cation decolorization 정도는 시료용액 첨가군과 무첨가군의 흡광도 감소율로 나타내었다.

\section{피부 각질충 손상 유도 및 육안평가}

임상피험자 선정 후 시험 부위에 $12 \mathrm{~mm}$ Finn chamber를 이용 하여 $1 \%$ sodium lauryl sulphate (SLS)를 chamber 내에 60 $\mu \mathrm{L}$ 적하하여 피험자의 시험부위에 첩포하여 피부각질층 손상을 
유도(-2D)한 후 24시간 후 첩포를 제거하고 시험부위를 가볍게 물로 닦고 30 분 후 시험부위를 관찰 및 측정(-1D) 하며 2주간 지속적으로 크림을 처방하면서 관찰하였다. 피부자극반응 육안 평가는 Frosch \& Kligman과 CTFA safety evaluation guidelines 에 따라 평가하였으며, 피부회복 정도 육안평가는 손상 유도 후 회복 정도를 손상 후 3-14일 후 2명 이상의 시험자가 육안 평 가기준에 의거하여 $0-4$ 단계 $(0$, 전혀 회복되지 않음; 1 , 미미하게 회복됨; 2 , 약간 회복됨; 3 , 회복됨; 4 , 완전히 회복됨)로 평가 하였다

\section{피부 수분량, 경피수분손실량 측정}

피부 각질층 아래 $30-40 \mu \mathrm{m}$ 의 수분량을 측정하는 기기 Corneometer $^{\mathbb{R}}$ CM825 (Courgae+Khazaka GmbH, Cologne, Germany)를 이용하여 피부의 수분 함량에 따른 피부표면의 전 기 전도도 값을 측정하여 수치화 하였다. 본 결과의 정확한 측 정치를 얻기 위해 평가시점마다 시험부위를 3회 반복 측정하였 다. 피부 표면의 경피수분손실량(transepidermal water loss, TEWL)은 피부장벽 기능을 지표 하는 것으로 보습기능과 밀접 한 관계를 가지고 있다. Vapometer ${ }^{\mathbb{R}} S W L-4001$ (Delfin, Kuopio, Finland) 장치의 온도, 습도 측정 센스가 측정 부위의 단위 면 적 당 시간 경과에 따른 수분 증발량을 측정하였다.

\section{피부색(홍반-a* value) 측정}

피부의 색 변화는 물체색의 분광반사율을 측정하여 명암, 적색, 녹색, 황색, 청색의 정도를 분석하는 분광광도계(Spectrophotometer ${ }^{\mathbb{R}}$ $C M-700 d$, Minolta, Tokyo, Japan)를 이용하였다. 시험부위를 각 각 3 회 반복 측정하여 평균값을 취하여 분석하였다.

\section{사용감 설문평가}

피부 각질층 손상 후 크림 사용에 따른 피험자의 주관적 개선 효과와 크림에 대한 만족도를 평가하였다.

\section{통계분석}

모든 실험은 3 회 반복으로 행하여 평균과 표준편차로 나타내었 고 피부 손상유도 시점별 차이 유무를 $\mathrm{SPSS}^{\circledR} 22.0$ 를 사용하여 통계 분석하고 유의성을 검증하였다(유효 편차 $p<0.05$ ).

\section{결과 및 고찰}

\section{식물복합추출물의 항산화 활성}

본 연구에서 사용된 식물복합추출물에서의 항산화 활성은 Table 2에 나타난 바와 같다. 일반적으로 페놀성 화합물은 자연계에 널리 분포하는 2 차 대사산물로서 그 함량은 식물의 항산화력과 정의 상관관계를 나타내고 있다(Suh 등, 2010). 앞서 연구에서 (Kim 등, 2015) 각 식물체의 총 페놀 함량(total phenolic contents, $\mathrm{TPC}$ )은 오배자의 경우 $302 \mathrm{mg} \mathrm{GA} / \mathrm{g}$ extract, 소목 $182 \mathrm{mg}$ $\mathrm{GA} / \mathrm{g}$ extract, 빈랑 $61 \mathrm{mg} \mathrm{GA} / \mathrm{g}$ extract, 소리쟁이 $36 \mathrm{mg} \mathrm{GA} / \mathrm{g}$ extract, 황련 $26 \mathrm{mg} \mathrm{GA} / \mathrm{g}$ extract, 황백 $15 \mathrm{mg} \mathrm{GA} / \mathrm{g}$ extract, 치자 $2 \mathrm{mg} \mathrm{GA} / \mathrm{g}$ extract을 나타내었는데, 본 연구에서 식물복 합추출물의 총 페놀 함량은 $132.2 \mathrm{mg} \mathrm{GA} / \mathrm{g}$ extract을 나타내어
Table 2 Total phenolic contents (TPC), DPPH and ABTS radical scavenging activity of plant extracts

\begin{tabular}{cccc}
\hline & $\mathrm{TPC}$ & $\mathrm{DPPH}$ & $\mathrm{ABTS}$ \\
& $(\mathrm{mg} / \mathrm{g})$ & $\left(\mathrm{IC}_{50}, \mu \mathrm{g} / \mathrm{mL}\right)$ & $\left(\mathrm{IC}_{50}, \mu \mathrm{g} / \mathrm{mL}\right)$ \\
\hline 5 plant extracts & 132.2 & $46.1 \pm 0.4$ & $11.2 \pm 0.2$ \\
Ascorbic acid & - & $15.6 \pm 0.3$ & $3.2 \pm 0.1$ \\
\hline
\end{tabular}

The values are expressed as mean and standard deviation

Table 3 Visual assessment of skin recovery before and after product use

\begin{tabular}{ccc}
\hline \multirow{2}{*}{$\begin{array}{c}\text { Time } \\
\text { (day) }\end{array}$} & \multicolumn{2}{c}{ Grade (Mean \pm SD) } \\
\cline { 2 - 3 } A D & $0.00 \pm 0.00$ & $\mathrm{~B}$ \\
\hline 3 D & $1.64 \pm 0.78$ & $0.00 \pm 0.00$ \\
6 D & $2.31 \pm 0.62$ & $1.36 \pm 0.78$ \\
$10 \mathrm{D}$ & $2.98 \pm 0.64$ & $1.76 \pm 0.78$ \\
$14 \mathrm{D}$ & $3.48 \pm 0.60$ & $2.17 \pm 0.83$ \\
\hline
\end{tabular}

$\mathrm{A}$ is a cream containing plant extracts and $\mathrm{B}$ is a base cream (control)

오배자, 소목보다는 적지만 다른 식물체에 비해서는 훨씬 많은 $\mathrm{TPC}$ 를 함유하여 우수한 항산화력을 보일 것으로 판단된다. 또 한, $\mathrm{DPPH}$ 와 $\mathrm{ABTS}$ 라디칼을 $50 \%$ 소거하는데 필요한 식물복 합추출물의 농도가 각각 $46.1,11.2 \mu \mathrm{g} / \mathrm{mL}$ 로 이는 비교 물질로 사용된 ascorbic acid와 비교하여 손색이 없을 정도의 높은 수 준인 것으로 판단된다.

\section{육안평가}

피부손상 유도를 위해 각 시험부위에 $1 \% \mathrm{SLS}$ 를 24 시간 첩포 하고, 첩포 제거 후 24시간 후 시험부위의 피부자극 정도를 점 수화 하여 평가하였다. 식물복합추출물 함유 보습크림제품(시험 구 $\mathrm{A}$ )과 기존 제형의 보습크림제품(대조구 $\mathrm{B}$ )에서 각각 1.86 과 1.90 의 손상이 유도 되었으며, 이 피부 각질층 손상 후 시험구 $\mathrm{A}$ 와 대조구 $\mathrm{B}$ 를 사용하면서 시험부위의 피부 회복 정도를 2 명 의 시험자에 의해 0-4 grade로 육안평가 하였다(Table 3). 시험 구 $\mathrm{A}$ 와 대조구 $\mathrm{B}$ 를 사용 전과 비교하여 두 그룹 모두 시간경 과에 따라 유의적으로 피부회복 정도가 증가되었으며 이러한 결 과는 시간경과에 따른 자연치유로도 보이나 회복의 정도에 있 어서 식물복합추출물이 함유되어 있는 시험구 $\mathrm{A}$ 가 대조구 $\mathrm{B}$ 보 다 회복 정도가 우수하였다.

\section{피부 수분량 측정}

Fig. 1은 시간 경과에 따른 피부 수분량의 변화를 나타내었다. 모 든 시험부위에서 피부 각질층 손상전과 비교 시 손상유도 후($1 \mathrm{D}, 0 \mathrm{D})$ 에 수분량이 증가하였다가 회복을 위한 피부반응으로 제품사용 3 일 이후 감소하는 경향을 보이며 시간이 경과함에 따라 다시 회복하는 경향을 보였다. 특히 시험구 $\mathrm{A}$ 에서 제품사 용 10 일 경과 시 피부손상 전보다 높은 수준의 수분함량이 분 석되었다. 반면 대조구 $\mathrm{B}$ 에서는 실험 2주간 회복되지 않는 것 으로 분석되었다. 이러한 수분함량 분석 결과만을 볼 때 5종의 식물복합추출물이 함유되어 있는 보습크림제품군의 보습능력이 기존의 보습크림제품군에 대해 월등하다는 것을 알 수 있다. 


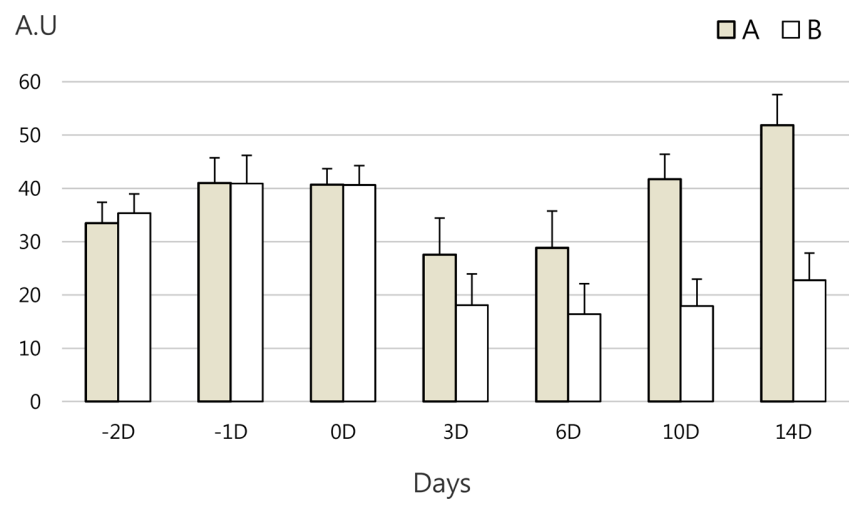

Fig. 1 Changes in skin moisture content by time. The data are expressed mean $\pm \mathrm{SD}$ of triplicate experiments. Dark gray bar is a cream containing plant extracts and open bar is a base cream (control)

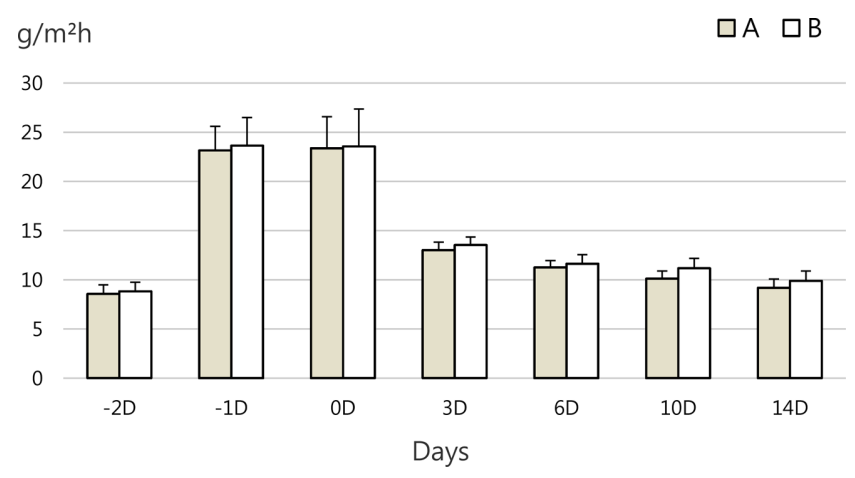

Fig. 2 Changes in skin transepidermal water loss by time. The data are expressed mean $\pm \mathrm{SD}$ of triplicate experiments. Dark gray bar is a cream containing plant extracts and open bar is a base cream (control)

\section{경피수분손실량(TEWL) 측정}

경피수분손실량의 분석은 피부로부터 발산되는 수분의 량을 측 정하는 것으로 피부장벽 기능의 지표이며, 보습기능과 밀접한 관계를 가지고 있어 중요한 분석법이다. 시험구 $\mathrm{A}$ 에서 피부손 상 유도 전(-2D)과 제품 사용 14일 후(14D) 시점에서 비교할 때 경피수분손실량의 통계적 유의차가 없으므로 피부손상 전으 로 회복 되었다고 판단할 수 있으며, 대조구 $\mathrm{B}$ 에서는 통계적 유의차가 보이므로 회복되지 않았다고 판단된다(Fig. 2). 이러한 결과로 보아 시험구 $\mathrm{A}$ 의 시료는 피부장벽 강화 및 보습기능이 우수한 것으로 판단할 수 있으며 환경 및 유전적 요인에 의한 피부질환 등에도 적용이 가능할 수 있으리라 판단된다.

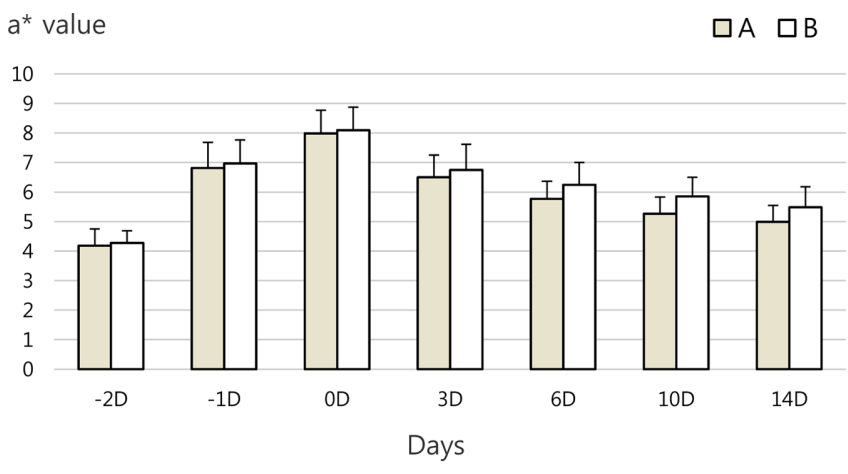

Fig. 3 Determination of erythema reaction by time. The data are expressed mean $\pm \mathrm{SD}$ of triplicate experiments. Dark gray bar is a cream containing plant extracts and open bar is a base cream (control)

\section{피부색(홍반-a* value) 측정}

시간경과에 따른 피부홍반 정도는 Fig. 3에 나타내었다. 피부손 상 전(-2D)과 비교시 손상유도 후(0D)에서 피부 홍반정도가 가 장 높게 증가하였다가 시험품 사용 3 일 이후 감소하는 경향을 보였다. 시험품 사용 14 일(14D) 시점에서 시험구 $\mathrm{A}$ 는 $19.38 \%$, 대조구 $\mathrm{B}$ 는 $37.29 \%$ 의 홍반 증가율을 보였다. 피부손상 유도전 과 비교하여 통계적 유의차이가 나타나므로 피부색은 완벽히 회 복되었다고 판단할 수 없다. 그러나 시험구 $\mathrm{A}$ 의 피부 홍반정도 가 대조구 $\mathrm{B}$ 에 비해 통계적으로 유의하게 감소된 것은 개선의 효과가 있다고 판단된다.

\section{설문평가}

시험품 사용 6 일(6D)과 14 일(14D) 후 연구대상자들이 설문을 통해 답변한 효능에 대한 평가 결과를 Table 4에 나타내었다. $6 \mathrm{D}$ 시점에서 시험구 $\mathrm{A}$ 에서 연구대상자들의 $55 \%$ 이상이 대조 구 $\mathrm{B}$ 에 비해 피부색 개선과 피부회복 개선에 긍정적이었다고 응답하였고, $14 \mathrm{D}$ 시점에는 $90 \%$ 이상이 긍정적으로 피부개선이 되었다고 응답하였다.

본 연구에서 5 종(비단풀, 황백, 홍화, 치자 및 오배자)의 식물 복합추출물이 함유된 보습크림(시험구 A)과 식물복합추출물이 함유되지 않은 보습크림(대조구 B)에 대한 피부자극 개선에 대 한 평가를 수행하였다. 피부회복 정도에 대한 육안평가에서 두 그룹 모두 시간경과에 따른 피부회복 정도가 증가 되었으나 회 복 정도에 있어서 시험구 $\mathrm{A}$ 가 대조구 $\mathrm{B}$ 보다 우수하였다. $\mathrm{A}$ 는 시험품 사용 6 일 후 시점에서 $\mathrm{B}$ 군에 비해 통계적으로 유의하 게 피부 회복 정도가 개선되었다. 기기평가를 수행한 피부 수

Table 4 The analysis of satisfaction survey for used samples

\begin{tabular}{|c|c|c|c|c|c|}
\hline & \multirow{2}{*}{ Group } & \multicolumn{2}{|c|}{$6 \mathrm{D}$} & \multicolumn{2}{|c|}{$14 \mathrm{D}$} \\
\hline & & Positive response & Satisfaction (\%) & Positive response & Satisfaction (\%) \\
\hline \multirow{2}{*}{ Improvement of skin color } & A & 12 & 57.14 & 19 & 90.48 \\
\hline & $\mathrm{B}$ & 1 & 4.76 & 12 & 57.14 \\
\hline \multirow{2}{*}{ Improvement of skin recovery } & A & 13 & 61.90 & 20 & 95.24 \\
\hline & $\mathrm{B}$ & 2 & 9.52 & 13 & 61.90 \\
\hline
\end{tabular}

$\mathrm{A}$ is a cream containing plant extracts and $\mathrm{B}$ is a base cream (control) 
분량, 경피수분손실량 분석에서도 14 일 이후 회복됨을 보였다. 피부 홍반량 분석에서는 피부손상 유도 전으로의 완전한 회복 은 되지 않았으나 시험구 $\mathrm{A}$ 군의 피부 홍반량이 대조구 $\mathrm{B}$ 군 에 비해 통계적으로 유의하게 감소하였다. 결론적으로 본 시험 품(식물복합추출물 함유 크림)은 인체 피부자극 유도 후의 피부 자극 완화 효과 평가를 통해 피부자극 완화 및 개선에 도움을 주는 것으로 판단된다.

\section{초 록}

이 연구의 목적은 5 종의 식물추출물을 함유하는 보습력이 우수 한 보습크림을 개발하여 피부개선 효능을 평가하는 것으로, 비 단풀, 황백, 홍화, 치자, 오배자의 복합추출물을 함유하는 보습 크림과 이를 포함하지 않는 보습크림 간의 임상연구를 수행하 였다. 21 명의 피험자에 대해 효과분석이 이루어졌으며, 각각의 분석은 3 회 반복 하여 검증하였다. 식물유래 복합추출물이 함 유된 보습크림(A)과 함유되지 않은 크림(B)과의 수분함량 비교 분석에서 $\mathrm{A}$ 크림이 $\mathrm{B}$ 크림에 비해 $50 \%$ 이상 높은 수준의 보 습력을 지니고 있으며, 피부 경피수분손실량 및 홍반반응 분석 에서도 $\mathrm{A}$ 크림이 $\mathrm{B}$ 크림에 비해 유의성 있는 개선효과를 나타 내었다. 결론적으로 식물복합추출물이 함유된 크림은 인체 피부 자극 유도 후의 피부자극 완화 효과 평가를 통해 피부자극 완 화 및 개선에 도움을 줄 수 있을 것으로 판단되고, 관련 산업 분야의 다양한 응용성을 가질 것으로 판단된다.

Keywords 경피수분손실 - 보습크림 - 항산화제 · 홍반반응

감사의 글 본 연구는 2014년도 대구대학교 학술연구비 지원에 의한 논문이 며, 이에 감사드립니다.

\section{References}

Ali KA, Abdelhak M, George B, Panagiotis K (2005) Tea and herbal infusions: Their antioxidant activity and phenolic propolis. Food Chem 89: $27-36$

An DH, Cho SJ, Jung ES, Lee HJ, Hwang JH, Park EJ, Park HR, Lee SC (2006) Antioxidant and anticancer activities of water extracts from Ceramium kondoi. J Korean Soc Food Sci Nutr 35(10): 1304-1308

Choi YE, Ahn HS (2010) The effect of microneedle therapy system to improve the facial skin conditions for mid-aged women. Kor J Aesthet Cosmetol 3: 611-618

Craig WJ (1997) Phytochemicals : Guardians of our health. J Am Diet Assoc 97: 199-204

Dabas D, Elias RJ, Lambert JD, Ziegler GR (2011) A colored avocado seed extract as a potential natural colorant. J Food Sci 76: C1335-C1341

Elzaawely AA, Xuan TD, Tawata S (2005) Antioxidant and antibacterial activites of Rumex japonicus Houtt. Biol Pharm bull 28: 2225-2230

Kim YS, Suh HJ, Park S (2015) Antioxidant activity of hot-water extracts and floral waters from natural plant pigments. Korean J Food Preserv 22(1): 129-133

Kwon YR, Lee HR, Hwang SH, Kwon OJ, Youn KS (2016) Antioxidant activities and physiological properties of Euphorbia humifusa extracts prepared using different solvents. Korean J Food Preserv 23(2): 252-258

Roberta R, Nicoletta P, Anna P, Ananth P, Min Y, Catherine RE (1999) Antioxidant activity applying an improved ABTS radical cation decolorization assay. Free Radi Biol Medi 26: 1231-1237

Sato M, Ramarathnam N, Suzuki Y, Ohkubo T, Takeuchi M, Ochi H (1996) Varietal differences in the phenolic content and superoxide radical cavenging potential of wines from different sources. J Agric Food Chem 44: $37-41$

Suh HJ, Kim SR, Lee KS, Kang SC (2010) Antioxidant activity of various solvent extracts from Allomyrina dichotoma (Arthropoda: Insecta) larvae. J Photochem Photobiol B 99: 67-73

Szabo MR, Iditoiu C, Chambre D, Lupea AX (2007) Improved DPPH determination for antioxidant activity spectrophotometric assay, Institute of Chemistry. Slovak Aca Sci 61: 214-216

Won JH, Shin JS, Park HJ, Jung HJ, Koh DJ, Jo BG, Lee JY, Yun K, Lee KT (2010) Anti-inflammatory effects of madexassic acid via the suppression of NF-kappaB pathway in LPS-induced RAW 264.7 macrophage cells. Planta med 76(3): 251-257 